\title{
Intraovarian release of eggs in the rat after indomethacin treatment at pro-oestrus
}

\author{
P. Osman and J. Dullaart \\ Department of Anatomy, Medical Faculty, Erasmus University, Rotterdam, \\ The Netherlands
}

Indomethacin has been shown to block ovulation in rats (Armstrong \& Grinwich, 1972; Tsafriri, Lindner, Zor \& Lamprecht, 1972a; Orczyk \& Behrman, 1972) and other mammals (O'Grady, Caldwell, Auletta \& Speroff, 1972; Grinwich, Kennedy \& Armstrong, 1972; Saksena, Lau \& Shaikh, 1974). The release of LH is not affected in indomethacin-treated rats (Tsafriri et al., 1972b), and it has been suggested that indomethacin exerts its ovulation-inhibiting action at the ovary (Grinwich et al., 1972; Tsafriri et al., 1972a; Saksena et al., 1974). It is not clear, however, how indomethacin affects the mechanism of ovulation, and in the present study the ovaries of rats treated with indomethacin at pro-oestrus were examined histologically.

Adult female rats of the Wistar substrain R'Amsterdam and weighing 180-200 $\mathrm{g}$ were used after two consecutive 5-day cycles. Indomethacin (Indocid capsules: Merck, Sharp \& Dohme) was suspended in $0.5 \mathrm{ml} 5 \%$ gelatin for s.c. injection.

\section{Experiment I}

Pro-oestrous rats were injected with various doses of indomethacin (Table 1) before and after the critical period, i.e. at 10.00 and 17.00 hours. Control animals were injected with vehicle only (Merck, Sharp \& Dohme) in $5 \%$ gelatin. All animals were killed at 10.00 hours the day after injection. The weights of the ovaries and uterus were recorded. The presence of eggs in the oviducts was checked by examining the oviducal contents under a dissection microscope. The ovaries were fixed in Bouin's fluid, embedded in paraffin wax, and serial $10 \mu \mathrm{m}$ sections were stained with haematoxylin and eosin.

Table 1. Effects of indomethacin treatment at pro-oestrus on ovulation in adult rats (means \pm S.E.M.)

\begin{tabular}{|c|c|c|c|c|c|c|}
\hline \multirow[b]{2}{*}{$\begin{array}{c}\text { Dose/rat } \\
(\mathrm{mg})\end{array}$} & \multirow[b]{2}{*}{$\begin{array}{c}\text { Time of } \\
\text { administration } \\
\text { (hours) }\end{array}$} & \multirow[b]{2}{*}{$\begin{array}{l}\text { No. of rats } \\
\text { ovulating/ } \\
\text { no. treated }\end{array}$} & \multirow{2}{*}{$\begin{array}{l}\text { No. of } \\
\text { CL and } \\
\text { luteinized } \\
\text { follicles }\end{array}$} & \multicolumn{3}{|c|}{ No. of eggs/rat } \\
\hline & & & & $\begin{array}{c}\text { In } \\
\text { oviducts }\end{array}$ & $\begin{array}{c}\text { In } \\
\text { Juteinized } \\
\text { follicles }\end{array}$ & $\underset{\text { interstitium }}{\text { In }}$ \\
\hline \multirow[t]{2}{*}{$2 \cdot 5$} & 10.00 & $2 / 6$ & $11 \cdot 8 \pm 0.3$ & $0.8 \pm 0.5$ & $6.8 \pm 0.8$ & $3.7 \pm 1.0$ \\
\hline & 17.00 & $5 / 7$ & $11 \cdot 6 \pm 0.4$ & $1 \cdot 1 \pm 0 \cdot 3$ & $5.9 \pm 0.8$ & $3.4 \pm 0.7$ \\
\hline \multirow[t]{2}{*}{$5 \cdot 0$} & 10.00 & $3 / 6$ & $12 \cdot 0 \pm 0.4$ & $0.5 \pm 0.2$ & $7 \cdot 2 \pm 1 \cdot 1$ & $3.7 \pm 0.6$ \\
\hline & 17.00 & $6 / 7$ & $11 \cdot 1 \pm 0.6$ & $1.7 \pm 0.4$ & $4 \cdot 9 \pm 1 \cdot 1$ & $3.7 \pm 1.0$ \\
\hline \multirow[t]{2}{*}{$8 \cdot 0$} & 10.00 & $0 / 4$ & $11 \cdot 5 \pm 0 \cdot 5$ & 0 & $9.5 \pm 0.9$ & $1.8 \pm 0.5$ \\
\hline & 17.00 & $3 / 4$ & $12 \cdot 0 \pm 0.6$ & $1 \cdot 3 \pm 0 \cdot 4$ & $8 \cdot 0 \pm 1 \cdot 3$ & $2 \cdot 5 \pm 1 \cdot 0$ \\
\hline 0 (vehicle only) & $\left\{\begin{array}{l}10.00 \\
17.00\end{array}\right.$ & $9 / 9$ & $10.6 \pm 0.6$ & $9.8 \pm 0.7$ & $0.8 \pm 0.5$ & 0 \\
\hline
\end{tabular}

After indomethacin treatment, ovulation was blocked in a number of animals and those that did ovulate had low numbers of oviducal eggs. Treatment at 10.00 hours seemed to be more effective in preventing ovulation than treatment at 17.00 hours. In the ovarian sections of the treated animals, eggs were frequently seen in follicles in which the granulosa cells had begun to luteinize and a clear stigma was usually present (Pl. 1, Fig. 1). The histological features of these luteinizing follicles or corpora lutea accessoria were identical to those of true corpora lutea in the ovaries of the control 
animals. Accessory corpora lutea were occasionally observed in control ovaries but an apparent stigma was never seen. Eggs were sometimes found in the ovarian interstitium, but neither they nor those still trapped in the luteinizing follicles could be distinguished from oviducal eggs; cumulus cells and stages of the second meiotic division with the first polar body (PI. 1, Fig. 2) were often seen. 'Interstitial' eggs were found in the dense extrafollicular tissue, beneath the tunica albuginea (PI. 1, Fig. 4), or in spaces filled with fluid (PI. 1, Fig. 3) and were always close to luteinized follicles with a recognizable stigma. Since the position of the stigma and the nature of the spaces in which the "interstitial' eggs were found could be checked in the serial sections, there was never any doubt that the eggs were released from neighbouring luteinized follicles. Intraovarian release of eggs was not observed in any of the control ovaries. A slight discrepancy was found between the total number of corpora lutea and luteinized follicles and the number of eggs in the oviducts and interstitium. This was probably due to the fact that interstitial eggs could be easily overlooked in the sections. Ovarian and uterine weights were not affected by the indomethacin treatment.

\section{Experiment II}

The effect of indomethacin on the preovulatory release of gonadotrophins was re-examined. Pro-oestrous rats were injected with $5 \mathrm{mg}$ indomethacin/rat at 10.00 or 14.00 hours and blood was obtained at $\mathbf{1 7 . 0 0}$ hours by puncture of the ophthalmic venous plexus. Serum concentrations of $\mathbf{L H}$ and FSH were determined by the micro-radioimmunoassay described previously (Welschen et al., 1975). The concentrations of FSH and LH were similar in the treated and control animals. FSH levels (ng rat-FSH-RP1/ml) were $166.3 \pm 19.0$ (S.E.M.) after treatment at 10.00 hours $(\mathrm{N}=5$ ), $169.9 \pm 29.9$ after treatment at 14.00 hours $(\mathrm{N}=4)$ and $164 \cdot 1 \pm 34 \cdot 6$ for the controls $(\mathrm{N}=4)$. LH levels (ng rat-LH-RP1/ml) were $988 \cdot 3 \pm 205 \cdot 7,959 \cdot 2 \pm 160 \cdot 4$ and $1019 \cdot 9 \pm 114 \cdot 6$, respectively. The disturbance to ovulation and the histological abnormalities seen in the indomethacin-treated rats in Exp. I were also found in this experiment.

\section{Discussion}

The present results confirm that indomethacin (1) inhibits ovulation; (2) does not affect LH release; and (3) acts at the ovary. The results also show that the preovulatory release of FSH is unaffected. The histological observations suggest that indomethacin affects the ovarian mechanism of ovulation by inducing the release of eggs from the follicles through 'misplaced' stigmata. The formation of stigmata indicates that indomethacin does not inhibit the enzymatic processes leading to the disintegration of the follicular wall before ovulation, but somehow affects the site of formation of the stigma. Since indomethacin is known as a potent inhibitor of prostaglandin synthesis (Vane, 1971), it is tempting to assume that a possible role of prostaglandins in the mechanism of ovulation is facilitation of the formation of a weak spot at the follicular apex, either by promoting rapid follicular distension, which is caused by influx of blood transudate (Lipner, 1973), and/or by promoting interstitial oedema formation in the ovarian medulla, which has been claimed to be the causal factor of

\section{EXPLANATION OF PLATE}

Fig. 1. An ovum trappod in a luteinizing follicle with a 'misplaced' stigma (arrowed) in a rat treated with $5 \mathrm{mg}$ indomethacin at 10.00 hours. $\times 90$.

Fig. 2. A luteinizing follicle with a 'misplaced' stigma in which the ovum can be seen, in a rat after treatment with $2.5 \mathrm{mg}$ indomethacin at 17.00 hours. $\times 90$. Inset: Detail of the ovum at early metaphase, with the disintegrating polar body (arrow head) pressed against the ooplasm. The corona radiata cells (arrowed) lie in close contact with the thecal layer. $\times 225$.

Fig. 3. An ovum surrounded by dispersed cumulus cells in a fluid-filled space in the stroma of a rat treated with $8 \mathrm{mg}$ indomethacin at 10.00 hours. The stigma is not in the plane of the section. No egg was found inside the luteinized follicle in the serial sections. $\times 90$.

Fig. 4. An ovum of a rat treated with $5 \mathrm{mg}$ indomethacin at 10.00 hours has been released through the distinct stigma in the luteinized granulosa layer but arrested beneath the tunica albuginea (still intact) and the germinal epithelium. $\times 90$. 

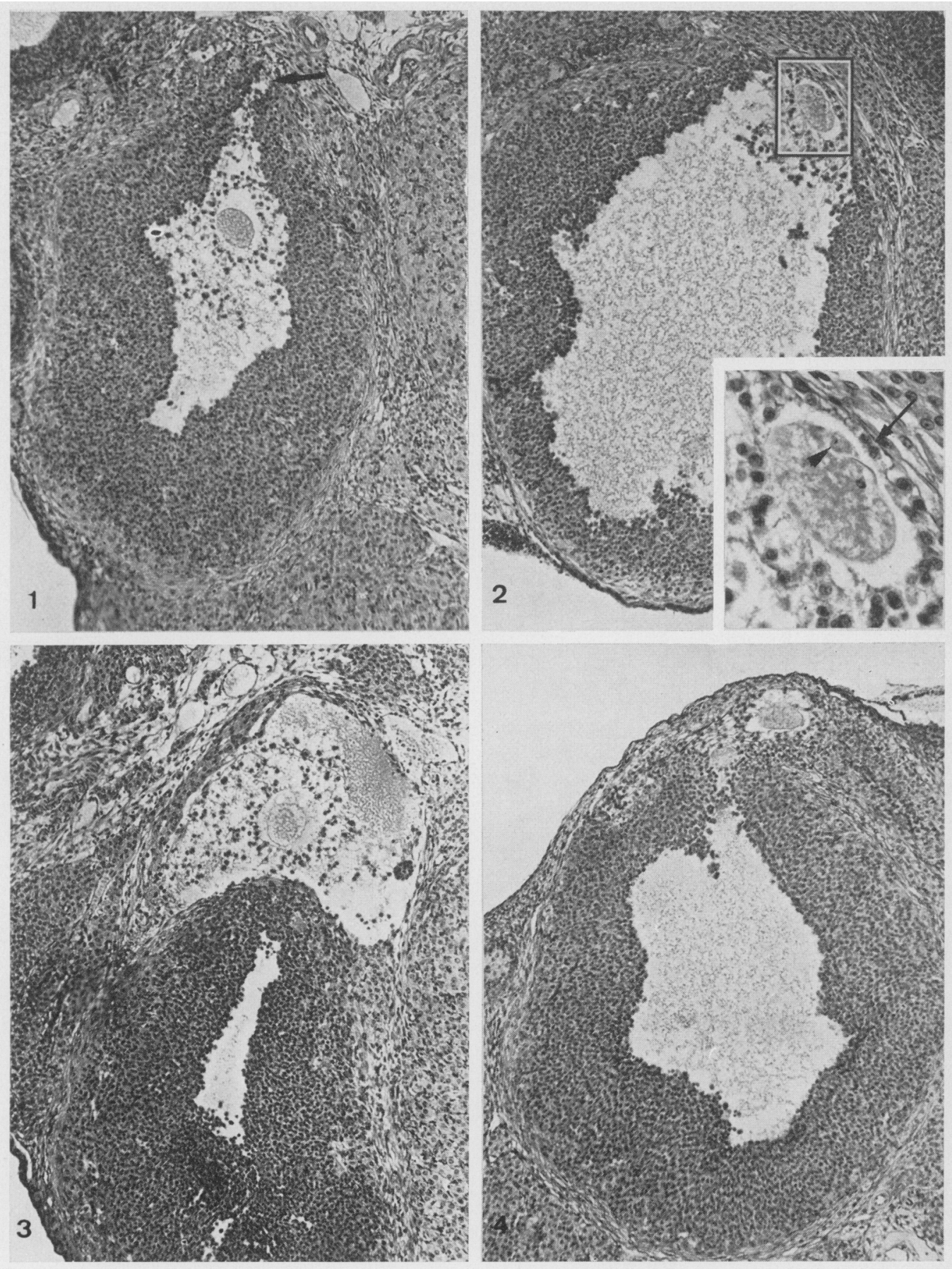

(Facing $p .102$ ) 
the preovulatory migration of the Graafian follicle towards the surface of the ovary (Burr \& Davies, 1951).

We thank Professor J. Moll for help with the manuscript; Miss P. C. Delfos for the photomicrographs; Merck, Sharp \& Dohme, Haarlem, The Netherlands, for the Indocid capsules and vehicle; and the NIAMDD for assay materials. The work was partly supported by The Organization for Medical Research in the Netherlands (FUNGO).

\section{References}

Armstrong, D.T. \& GrinwiCh, D.L. (1972) Blockade of spontaneous and $\mathbf{L H}$-induced ovulation in rats by indomethacin, an inhibitor of prostaglandin biosynthesis. Prostaglandins 1, 21-28.

BURR, J.H., JR \& DAvies, J.J. (1951) The vascular system of the rabbit ovary and its relationship to ovulation. Anat. Rec. 79, 113-331.

Grinwich, D.L., Kennedy, T.G. \& ARMSTRong, D.T. (1972) Dissociation of ovulatory and steroidogenic actions of luteinizing hormone in rabbits with indomethacin, an inhibitor of prostaglandin biosynthesis. Prostaglandins 1, 89-96.

LiPNER, H. (1973) Mechanism of mammalian ovulation. In Handbook of Physiology, Section 7, Vol. II: Female Reproductive System, pp. 409-437. Eds. R. O. Greep \& E. B. Astwood. American Physiological Society, Washington.

O'Grady, J.P., Caldwell, B.V., Auletta, F.J. \& SPERoFf, L. (1972) The effects of an inhibitor of prostaglandin synthesis (indomethacin) on ovulation, pregnancy and pseudopregnancy in the rabbit. Prostaglandins 1, 97-106.

OrCzYK, G.P. \& Behrman, H.R. (1972) Ovulation blockade by aspirin or indomethacin-in vivo evidence for a role of prostaglandin in gonadotrophin secretion. Prostaglandins 1, 3-20.

Saksena, S.K., LAU, I.F. \& ShalKh, A.A. (1974) Cyclic changes in the uterine tissue content of F-prostaglandins and the role of prostaglandins in ovulation in mice. Fert. Steril. 25, 636-643.

TSAFrirI, A., LINDNER, H.R., Zor, U. \& LAMPReCHT, S.A. (1972a) Physiological role of prostaglandins in the induction of ovulation. Prostaglandins 2, 110.

TSAFRIRI, A., LINDNER, H.R., ZOR, U. \& LAMPRECHT, S.A. (1972b) In-vitro induction of meiotic division in follicle-enclosed rat oocytes by $\mathrm{LH}$, cyclic AMP and prostaglandin $\mathrm{E}_{2}$. J. Reprod. Fert. 31, 3950.

VANE, J.R. (1971) Inhibition of prostaglandin synthesis as a mechanism of action for aspirin-like drugs. Nature, New Biol. 231, 232-235.

Welschen, R., Osman, P., Dullaart, J., de Greef, W.J., UiLeNBroeK, J.Th.J. \& DE JoNG, F.H. (1975) Levels of follicle stimulating hormone, luteinizing hormone, oestradiol-17 $\beta$ and progesterone and follicular growth in the pseudopregnant rat. $J$. Endocr. 64, 37-47.

Received 1 September 1975 